\title{
Binding and molecular weight properties of the insulin receptor from omental and subcutaneous adipocytes in human obesity
}

\author{
J. N. Livingston', K. M. Lerea ${ }^{1}$, J. Bolinder², L. Kager², L. Backman ${ }^{3}$ and P. Arner ${ }^{2}$ \\ ${ }^{1}$ Department of Medicine, University of Rochester, Rochester, New York, USA, \\ and Departments of Medicine and Surgery, ${ }^{2}$ Huddinge and ${ }^{3}$ Danderyd Hospitals, Karolinska Institute, Stockholm, Sweden
}

\begin{abstract}
Summary. The insulin binding properties and the molecular weights of the insulin receptor and its insulin binding subunit were studied in omental and subcutaneous adipocytes prepared from obese- and normal-weight subjects. Insulin binding by such adipocytes was decreased in obesity when the binding activity was expressed per unit of cell surface area. No significant difference from the lean controls was evident, however, when binding was calculated on a per cell basis, indicating that the total receptor content of the cells from the obese subjects was not altered. In addition, the normal difference in the receptor binding affinities previously reported between omental and subcutaneous cells from lean individuals was unaffected by the obese condition. Studies of the molecular weight of the non-reduced insulin receptor in fat cell membranes prepared from pieces of omental and subcutaneous fat demonstrated a major receptor species of $390-425 \mathrm{~K} \mathrm{M}$. In contrast, adipocytes isolated by collagenase treatment of the fat had heterogenous non-reduced receptor species of $M_{r}$
\end{abstract}

$355 \mathrm{~K}, 285 \mathrm{~K}$ and small amounts of $427 \mathrm{~K}$ and $182 \mathrm{~K}$. Although different non-reduced receptor species were evident depending on the adipocyte receptor preparation (e.g. isolated adipocytes or fat cell membranes), no differences were found between obese and lean controls or between subcutaneous and omental receptors when the appropriate comparisons were made. Upon sulphydryl reduction, all receptor preparations had a major binding subunit of $125 \mathrm{~K} \mathrm{M}_{\mathrm{r}}$. In conclusion, obesity is characterized by a dilution of the insulin receptor over the adipocyte cell surface in the absence of a change in total cellular content of receptors. The difference in insulin binding affinities between omental and subcutaneous adipocytes could not be explained by an alteration in receptor molecular weight.

Key words: Insulin receptor, obesity, adipocyte, subcutaneous fat, omental fat.
Obesity is a well recognized insulin resistant state in man [1]. A large amount of work has focussed on the inciting factor(s) that induces this resistance and on the alteration(s) in target cells responsible for the change [2]. One such area involves the insulin receptor and the possibility that a decrease in insulin binding contributes to the diminished insulin action reported in human adipocytes. Results from several of these studies have indicated a decrease in the total number of insulin receptors per adipocyte in obesity, which suggested that a change in receptor regulation might contribute to the hormonal resistance [3-6]. Other studies, however, have demonstrated a change only in the receptor density on the cell surface [7-9], a feature associated with increased size of the adipocytes.

All previous insulin binding studies in obesity have used adipocytes taken from subcutaneous fat even though omental adipose tissue forms a substantial part of the overall fat deposits [10]. In the present study, we have examined the insulin binding properties of omental adipocytes from obese- and normal-weight subjects and re-examined insulin binding by the subcutaneous cells. Since little is known of the structure of the human adipocyte receptor, affinity labelling procedures and so- dium dodecyl sulphate electrophoresis have been used to evaluate the molecular weight of the receptors in these tissues. This investigation also provided an opportunity to determine whether obesity alters the normal difference found in insulin-binding affinities of omental and subcutaneous receptors previously described in lean individuals [11].

\section{Subjects and methods}

\section{Human subjects}

Nine non-obese control subjects and seven obese subjects were studied. Their clinical data are given in Table 1 . The control subjects had uncomplicated gallstone disease, but were otherwise healthy and were admitted for elective cholecystectomy. They had not been on any special diets to help control gallstone formation. The obese subjects were otherwise healthy and were admitted for gastric operations for obesity. All subjects had maintained constant body weight during the 3 months preceding admittance, and none was on any specific treatment. All subjects were examined as in-patients but remained active at their usual exercise level. They were put on an isocaloric weight-maintaining diet ( $45 \%$ carbohydrate, $20 \%$ protein, and $35 \%$ fat) for 3 days. After an overnight fast, general anaesthesia was induced with a shortacting barbiturate and maintained by phentanyl and a nitrous oxideoxygen mixture. The specimens of adipose tissue (about $10 \mathrm{~g}$ ) were 
Table 1. Clinical and metabolic characteristics of the study groups

\begin{tabular}{|c|c|c|c|c|c|c|c|c|}
\hline & \multirow[t]{2}{*}{$\begin{array}{l}\text { Sex } \\
(F: M)\end{array}$} & \multirow[t]{2}{*}{$\begin{array}{l}\text { Age } \\
\text { (years) }\end{array}$} & \multirow[t]{2}{*}{$\begin{array}{l}\text { Height } \\
(\mathrm{cm})\end{array}$} & \multirow{2}{*}{$\begin{array}{l}\text { Body } \\
\text { weight } \\
\text { (kg) }\end{array}$} & \multirow{2}{*}{$\begin{array}{l}\text { Fasting blood } \\
\text { glucose level } \\
(\mathrm{mmol} / \mathrm{l})\end{array}$} & \multirow{2}{*}{$\begin{array}{l}\text { Fasting serum } \\
\text { insulin level } \\
(\mathrm{mU} / 1)\end{array}$} & \multicolumn{2}{|c|}{$\begin{array}{l}\text { Fat cell volume } \\
\left(\mathrm{mm}^{3} \times 10^{-6}\right)\end{array}$} \\
\hline & & & & & & & Omental & Subcutaneous \\
\hline Control subjects $(n=9)$ & $4: 5$ & $37 \pm 4$ & $173 \pm 3$ & $69 \pm 3$ & $4.7 \pm 0.2$ & $5.4 \pm 0.7$ & $469 \pm 61$ & $660 \pm 66$ \\
\hline Obese subjects $(n=7)$ & $4: 3$ & $36 \pm 5$ & $171 \pm 4$ & $130 \pm 9^{b}$ & $4.9 \pm 0.2$ & $32.7 \pm 8.1^{a}$ & $986 \pm 62^{b}$ & $1124 \pm 151^{a}$ \\
\hline
\end{tabular}

The values are expressed as mean \pm SEM. Significance between groups using Student's unpaired t-test: ${ }^{a} p<0.01 ;{ }^{b} p<0.001$

taken immediately after the abdominal wall had been opened. Subcutaneous fat first was removed from the surgical incision in the epigastric region of the abdominal wall and omental fat was taken from the major omentum. The time period from the start of the first to the end of the second biopsy was always less than 2 min.

The study was approved by the Ethical Committee of the Karolinska Institute. Each subject was given a detailed description of the study and informed consent was obtained.

\section{Fat cell determination and isolation of fat cells}

The fat cell size was measured in frozen-cut and formaldehyde-fixed adipose tissue, according to the method of Sjöstrom et al. [12]. In individual experiments, the diameters of 100 cells were determined with a calibrating photomicroscope (Zeiss, New York, USA). Mean fat cell volume, fat cell number and mean fat cell surface area were calculated by formulae described previously [13, 14]. Isolated fat cells were prepared using the method of Rodbell [15]. In brief, minced adipose tissue was shaken for $60 \mathrm{~min}$ at $37^{\circ} \mathrm{C}$ in Krebs-Henseleit bicarbonate buffer (pH 7.4), containing collagenase $(0.5 \mathrm{mg} / \mathrm{ml})$ and dialyzed bovine serum albumin $(20 \mathrm{mg} / \mathrm{ml})$. After the isolation procedure, the fat cells were washed three times with collagenase-free buffer.

\section{Preparation of adipose plasma membranes}

Plasma membranes were prepared at $0-4{ }^{\circ} \mathrm{C}$ as described by Belsham et al. [16]. A mixture of sucrose $(2 \mathrm{~mol} / \mathrm{l})$, Tris- $\mathrm{HCl}(80 \mathrm{mmol} / \mathrm{l})$ and EGTA ( $8 \mathrm{mmol} / 1)$ was prepared and adjusted to $\mathrm{pH} 7.4$ (buffer 1). Approximately $4 \mathrm{~g}$ of adipose tissue was homogenized for $10 \mathrm{~s}$ with a Polytron homogenizer, Brinkmann Instruments, Westbury, New York) in $10 \mathrm{ml}$ of sucrose $(0.25 \mathrm{~mol} / 1)$, Tris- $\mathrm{HCl}(10 \mathrm{mmol} / 1)$, EGTA ( $2 \mathrm{mmol} / \mathrm{l}), \mathrm{pH} 7.4$ (buffer 2). After centrifugation for $30 \mathrm{~s}$ at $1000 \mathrm{~g}$, the interphase between the fat plug and the pellet was aspirated and centrifuged for $30 \mathrm{~min}$ at $30,000 \mathrm{~g}$. The pellet was resuspended in $8 \mathrm{ml}$ of Percoll: buffer $1:$ buffer $2(7: 1: 32)$ and centrifuged for $15 \mathrm{~min}$ at $10,000 \mathrm{~g}$. One $\mathrm{ml}$ of the supernatant containing the plasma membranes was aspirated and diluted with buffer $2(5 \mathrm{ml})$ and centrifuged for $2 \mathrm{~min}$ at $10,000 \mathrm{~g}$. The pellet was suspended in $0.5 \mathrm{ml}$ of buffer 2 and stored at $-70^{\circ} \mathrm{C}$. When isolated fat cells were used for the preparation of plasma membranes, $2 \mathrm{ml}$ of packed adipocytes were homogenized in $10 \mathrm{ml}$ of buffer 2 and processed as described above.

\section{Insulin binding to isolated fat cells}

Isolated fat cells were incubated in triplicate at the final cell concentration of $8 \%(\mathrm{v} / \mathrm{v})$ for 60 min at $24^{\circ} \mathrm{C}$ in Krebs-Henseleit bicarbonate buffer ( $\mathrm{pH} 7.4)$, containing dialyzed bovine serum albumin $(40 \mathrm{mg} /$ $\mathrm{ml})$, glucose $(1 \mathrm{mg} / \mathrm{ml})$, mono ${ }^{125} \mathrm{I}-\left(\mathrm{Tyr} \mathrm{A}_{14}\right)$ insulin $(0.05 \mathrm{pmol} / \mathrm{ml})$ and the indicated concentration of unlabelled insulin. In these studies, the final insulin concentrations ranged from 0.05 to $50 \mathrm{pmol} / \mathrm{ml}$. The binding reaction was terminated by adding $\mathrm{NaCl}(0.154 \mathrm{mmol} / 1$, $10 \mathrm{ml}$ ) and the cells were subjected to centrifugation through $1.2 \mathrm{ml}$ of silicone oil [17]. Cell-bound radioactivity was determined in the cells suspended above the oil phase. Non-specific binding was approximately $4 \%$ of the total binding as determined by the addition of unla belled insulin $(20 \mu \mathrm{mol} / 1)$. Specific insulin binding was based on the fat cell number or the fat cell surface area. Binding data were presented both as a plot of the percentage of the specifically bound ${ }^{125} \mathrm{I}$. insulin versus the total insulin concentration (competition-inhibition curve) and according to Scatchard [18].

\section{Affinity labelling of intact fat cells with ${ }^{125}$ I-insulin}

Packed cells $(1.5 \mathrm{ml})$ were suspended in Krebs-Henseleit bicarbonate buffer ( $\mathrm{pH} 7.4,7 \mathrm{ml})$ containing albumin $(40 \mathrm{mg} / \mathrm{ml})$, glucose $(1 \mathrm{mg} /$ $\mathrm{ml}),{ }^{125} \mathrm{I}$-insulin prepared by the chloramine-T method $(0.5 \mathrm{pmol} / \mathrm{ml})$ and unlabelled insulin $(0$ or $20 \mu \mathrm{mol} / 1)$. The cells were incubated at $21^{\circ} \mathrm{C}$ for $60 \mathrm{~min}$. A solution of the cross-linking reagent, disuccinimidyl suberate $(0.1 \mathrm{ml})$ was then added $(0.5 \mathrm{mg} / \mathrm{ml}$, final concentration) and the incubation was continued for another $15 \mathrm{~min}$ at $21^{\circ} \mathrm{C} \mathrm{[19].} \mathrm{The}$ cross-linking reaction was terminated by the addition of $2 \mathrm{~mol} / \mathrm{l}$ Tris $\mathrm{HCl}(\mathrm{pH} 7.6,0.1 \mathrm{ml})$ containing $0.2 \mathrm{~mol} / 1 \mathrm{Na}$ EDTA. After removal of the medium, the fat cells were washed twice in $15 \mathrm{ml}$ of insulin-free incubation buffer and the plasma membranes were prepared as described above.

\section{Affinity labelling of adipocyte plasma membranes with ${ }^{125}$ I-insulin}

Adipocyte membranes (30-100 $\mu$ g protein) prepared from fat tissue were incubated at $21^{\circ} \mathrm{C}$ with ${ }^{125} \mathrm{I}$-insulin $(0.5 \mathrm{nmol} / \mathrm{l})$ in a Krebs Ring-

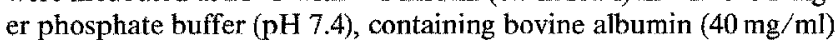
and bacitracin $(1 \mathrm{mg} / \mathrm{ml})$. Non-specific labelling was determined in a parallel experiment using $20 \mu \mathrm{mol} / 1$ unlabelled insulin. After a $2-\mathrm{h}$ incubation, disuccinimidyl suberate (final concentration $1 \mathrm{mmol} / \mathrm{l}$ ) was added [19] and the incubation continued for $10 \mathrm{~min}$. The reaction was terminated by the addition of the Tris, EDTA solution described above. The membranes were isolated by centrifugation and dissolved in the appropriate sodium dodecyl sulphate (SDS) solution for gel electrophoresis.

\section{SDS gel electrophoresis}

The affinity labelled membranes were solubilized and subjected to SDS electrophoresis by two different methods. Non-reduced affinity labelled receptors were solubilized in the absence of reductant and subjected to electrophoresis in a $3.3 \%$ SDS acrylamide gel as described by Weber et al. [20]. Following electrophoresis, the gels were fixed in 10\% trichloroacetic acid ( $\mathrm{w} / \mathrm{v}$ ), stained with Coomassie blue $\mathrm{R}-250$, destained and dried. The dried gels were exposed to X-omatic film ( $S$ and W X-rays, Rochester, New York) using X-omatic intensifying screens (Eastman-Kodak, Rochester, New York). The film was previously sensitized by preflashing with a flash unit (Sunpak, Berkey Co., Woodside, New York).

The subunit composition of the labelled receptors were determined by solubilizing the membranes in an SDS buffer containing $\beta$ mercaptoethanol $(100 \mathrm{mmol} / \mathrm{l})$ as described by Laemmli [21]. The electrophoresis was conducted in a $5-12 \%$ acrylamide gradient gel [21]. Autoradiographs of the gels were prepared as described above.

\section{Chemicals}

Crystalline porcine insulin was supplied by Vitrum, Stockholm, Sweden, and Eli Lilly, Indianapolis, Indiana. Collagenase was obtained from Worthington, Malverne, Pennsylvania, and Armour Pharmaceuticals, Kanakee, Illinois supplied bovine serum albumin. Disuccinimidyl suberate was purchased from Pierce Chemical, Rockford, Illinois. Acrylamide, N, N' methylenebisacrylamide, and $\mathrm{N}, \mathrm{N}, \mathrm{N}^{\prime}, \mathrm{N}^{\prime}$-tetramethylethylenediamine were supplied by Eastman Kodak, Rochester, New York. High molecular weight cross-linked standards $\left(M_{\mathrm{r}}\right.$ range of $\left.336,000-56,000\right)$ were purchased from British 

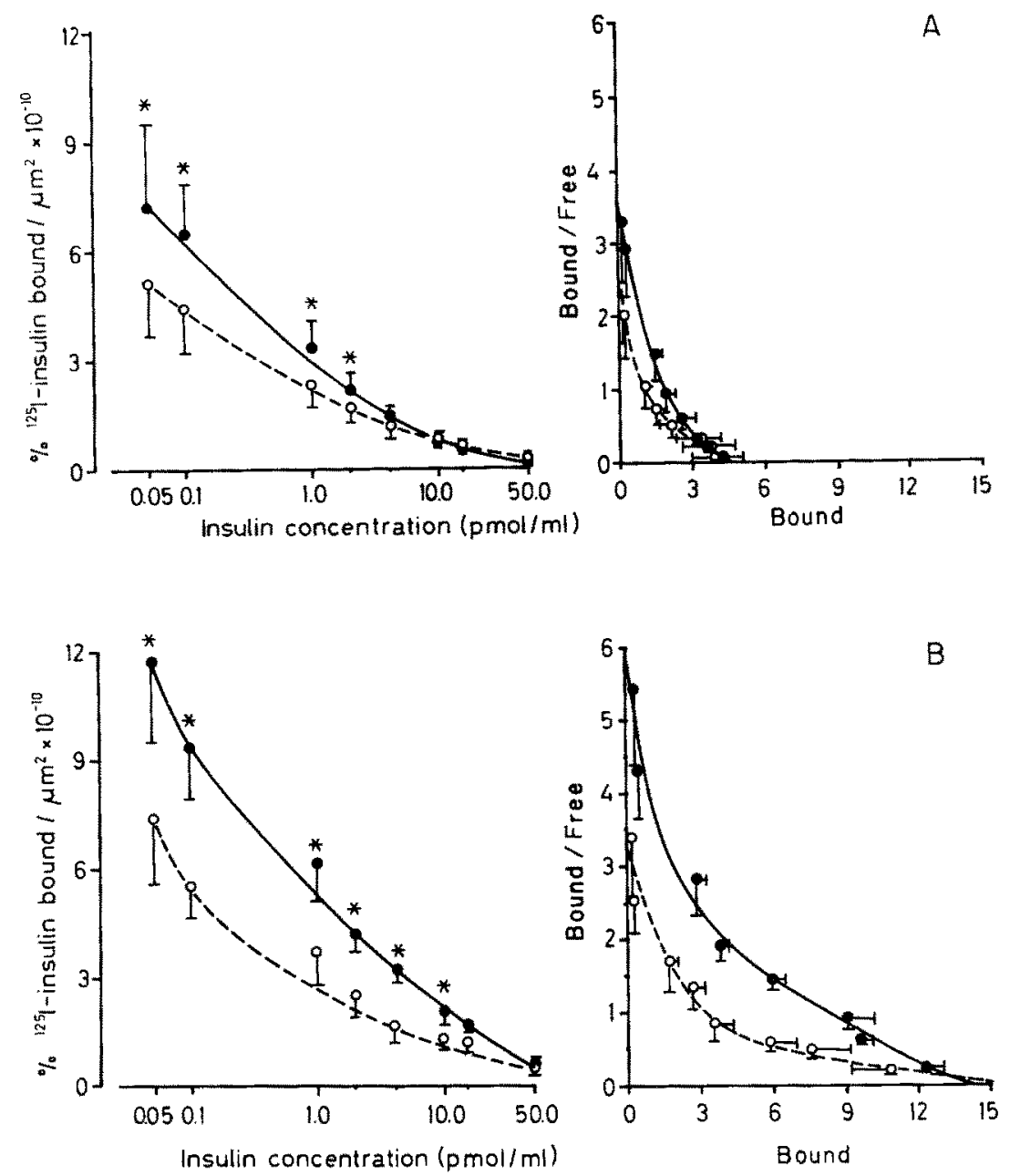

Fig. 1A and B. Insulin binding to adipocytes isolated from $\mathbf{A}$ obese and $\mathbf{B}$ non-obese subjects.

Subcutaneous $(-0)$ and omental $(\mathrm{O}-\mathrm{O})$ fat cells were isolated from five obese and five non-obese control subjects matched for age and sex. Specific insulin binding is expressed per unit cell surface area (mean \pm SEM). Left panels are competition-inhibition curves; right panels are the corresponding Scatchard plots. ${ }^{*} p<0.05$
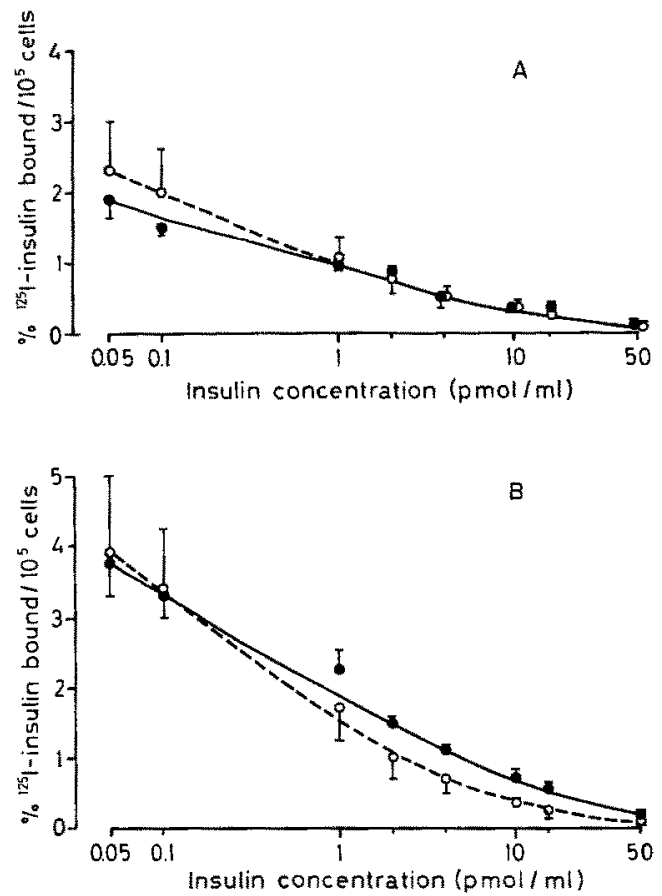

Fig. $2 \mathrm{~A}$ and B. Scatchard analysis of the insulin binding data of Figure 1 expressed per cell. Data for $\mathbf{A}$ omental and $\mathbf{B}$ subcutaneous fat cells isolated from $(-\infty)$ non-obese and $(\mathrm{O}-\mathrm{O}-\mathrm{O})$ obese subjects are shown. The two curves in each panel are not statistically different
Drug House Biochemicals, Dorset, Poole, UK. Bio-Rad, Richmond, California, supplied mid-range molecular weight standards $\left(M_{r}\right.$ range of $200,000-43,000)$. Mono ${ }^{125} \mathrm{I}-\mathrm{Tyr} \mathrm{A}_{14}$-insulin $(209 \mathrm{CV} / \mathrm{g})$ used in the insulin binding studies was purchased from Novo, Copenhagen, Denmark. The ${ }^{125} \mathrm{I}$-insulin used in the affinity labelling procedures was prepared by the chloramine-T method as described [22], using ${ }^{125} \mathrm{I}-\mathrm{Na}$ purchased from Amersham International, Amersham, Bucks, UK.

\section{Statistical analysis}

Reported values represent the mean \pm SEM. Student's paired and unpaired t-tests were used for statistical comparison of the data.

\section{Results}

All of the subjects had normal fasting blood glucose levels at the time of the study (Table 1). However, the mean fasting serum insulin level was six times higher in the obese than in the control group $(p<0.01)$, indicating that the obese subjects were insulin resistant. Table 1 also shows the increase in the volumes of both omental and subcutaneous fat cells from the obese individuals. In both groups subcutaneous cells were larger than the omental cells. 


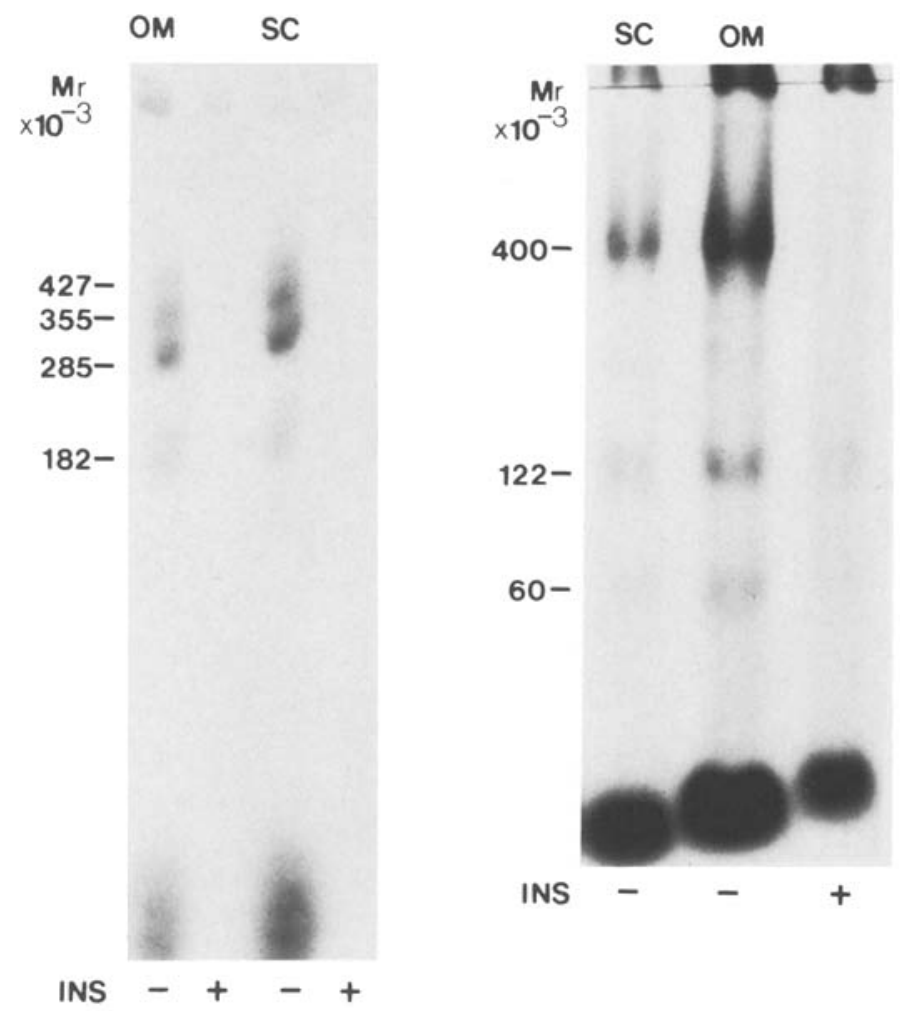

Fig.3. Structure of the non-reduced insulin receptor from isolated adipocytes and fat cell plasma membranes. Left panel: omental (OM) and subcutaneous (SC) adipocytes were isolated by collagenase treatment and affinity labelled with ${ }^{125} \mathrm{I}$-insulin in the presence $(+)$ or absence $(-)$ of native insulin. The labelled receptors were solubilized and subjected to SDS-PAGE and autoradiography. Right panel: adipocyte plasma membranes prepared from omental and subcutaneous fat pieces were affinity labelled with ${ }^{125} \mathrm{I}$-insulin and the structure of the receptor was examined as described above

\section{Studies of insulin binding}

The results of insulin binding to isolated fat cells expressed per cell surface area are illustrated in Figure 1. For both groups specific insulin binding was significantly higher in subcutaneous than omental cells at low insulin concentrations $(p<0.05)$. At higher insulin concentrations $(>10 \mathrm{pmol} / \mathrm{ml})$, there was no difference in binding between the two types of fat cells. Based on Scatchard analysis of the binding data, the difference in binding between omental and subcutaneous cells apparently was due to differences in overall affinity rather than differences in total binding sites. A difference in insulin binding between omental and subcutaneous fat cells was present also when binding was expressed per fat cell number, since subcutaneous cells are larger (Fig. 2).

Insulin binding to fat cells of obese and control subjects can also be reliably compared, since the two groups were matched for age and sex. The competitioninhibition curves show that specific insulin binding to subcutaneous fat cells is, on average, $40 \%$ lower in the obese than the control group (Fig. 1). The difference between the two groups for omental cells is approximately $30 \%$. The Scatchard plots demonstrate a parallel shift to the left for the obese group in relation to the control
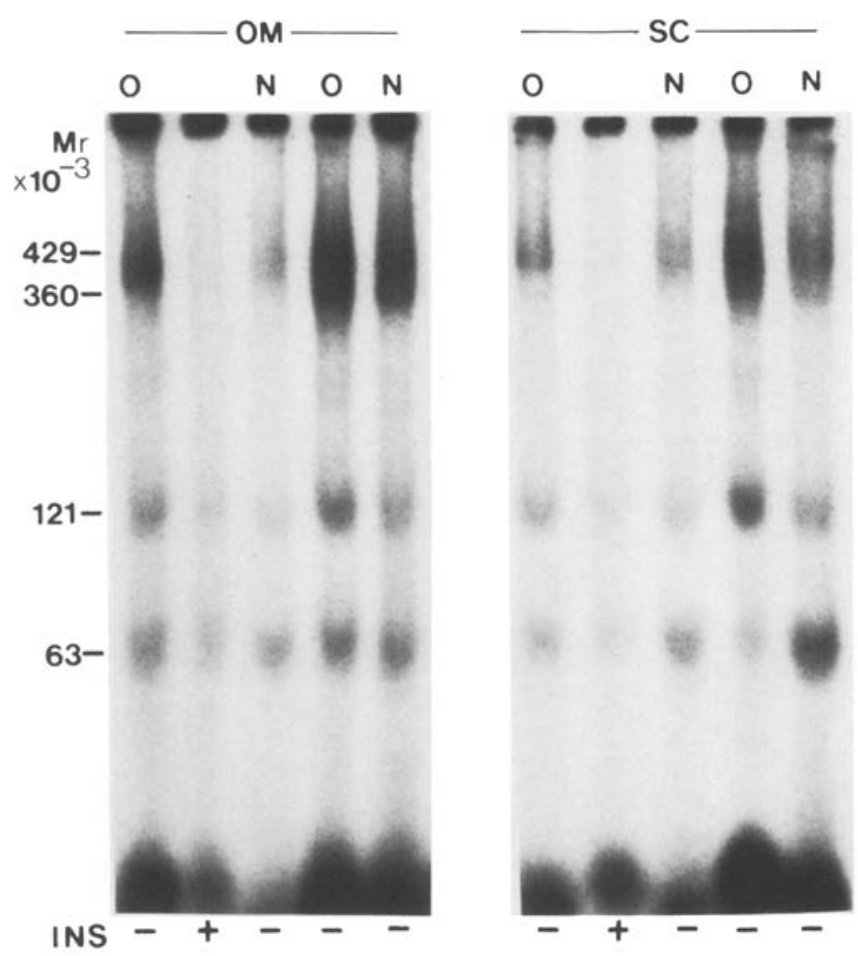

Fig. 4. The structure of the non-reduced insulin receptor from obese $(\mathrm{O})$ and normal weight $(\mathrm{N})$ subjects. Fat cell membranes were isolated from pieces of omental (OM) and subcutaneous (SC) tissue. Autoradiograms of the dried gels were prepared after SDS electrophoresis of the affinity labelled receptors. The presence $(+)$ and absence $(-)$ of excess native insulin (INS) during the labelling procedure is indicated

group for both omental and subcutaneous fat cells (Fig. 1). These data indicate that the decrease in insulin binding in the obese group was largely due to a decrease in total binding sites per unit of cell surface. When insulin binding was expressed per cell (Fig. 2), no significant difference between the adipocytes from obese subjects and controls was found in the high affinity portion of the Scatchard plots. In the lower affinity portion of the curve, e.g. $>5 \mathrm{nmol} / 1$ insulin, there was a slight but not statistically significant decrease in the extent of binding by subcutaneous cells from the obese group.

\section{Characteristics of the molecular weight of the adipocyte insulin receptor}

The molecular weight of the receptor was examined by cross-linking ${ }^{125}$ I-insulin to the insulin binding sites with disuccinimidyl suberate, followed by SDS polyacrylamide gel electrophoresis. This method was chosen because of its efficiency in covalently attaching radiolabelled insulin to the receptor [23].

Figure 3 (left panel) illustrates the non-reduced insulin receptor species found after cross-linking ${ }^{125} \mathrm{I}$-insulin to intact adipocytes isolated from subcutaneous and omental fat taken from the same subject. There are several specific insulin binding species ranging in mo- 


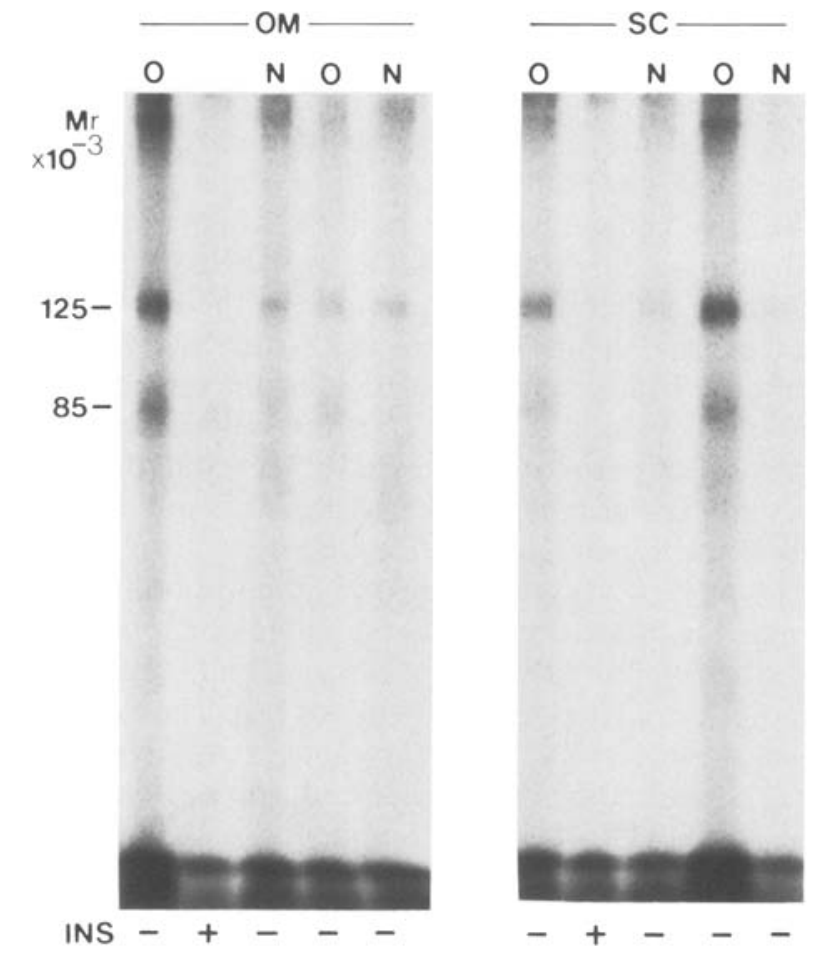

Fig. 5. Autoradiogram of the subunit composition of the adipocyte insulin receptor from obese $(O)$ and normal weight $(N)$ subjects. Fat cell membranes were prepared from omental $(\mathrm{OM})$ and subcutaneous (SC) fat pieces. The receptors were affinity labelled in the absence $(-)$ or presence $(+)$ of native insulin (INS) and subjected to electrophoresis after reduction with $100 \mathrm{mmol} / 1 \beta$-mercaptoethanol

lecular weight from $427 \mathrm{~K}$ to a small amount of $182 \mathrm{~K}$. The major species is a $285 \mathrm{~K}$ component; smaller but prominent amounts of insulin binding species of $355 \mathrm{~K}$ and $427 \mathrm{~K}$ are also evident. The $182 \mathrm{~K}$ is not clearly shown but is easily identified in the original autoradiogram.

Both omental and subcutaneous adipocytes contained these species and their relative amounts were similar in both tissues. Therefore, even though the insulin binding affinity was greater in subcutaneous cells, both cell types contained similar non-reduced insulin binding complexes that have similar or identical molecular weights.

The insulin receptor is highly sensitive to protease activity [24]. Since the collagenase used in preparing the isolated adipocytes contains a number of different proteases, we also studied plasma membranes isolated from pieces of subcutaneous and omental fat. In these studies the plasma membranes were purified by a Percoll gradient centrifugation technique, which previously was shown to separate a membrane fraction corresponding closely to the plasma membrane of isolated fat cells [16]. Figure 3 (right panel) shows the insulin binding species obtained from subcutaneous omental fat pieces. Clearly, there is a marked difference between these results and the findings obtained from isolated fat cells shown in the left panel. In the membranes isolated from the fat biopsies, a major $400 \mathrm{~K}$ insulin binding species is present with minor components of $122 \mathrm{~K}$ and $60 \mathrm{~K}$ $\mathrm{M}_{\mathrm{r}}$. Only the $400 \mathrm{~K}$ species binds insulin in a highly spe- cific manner, since the presence of a large amount of native insulin does not completely inhibit the labelling of the two minor bands with ${ }^{125}$ I-insulin. Consequently, in membranes isolated in the absence of collagenase treatment, the major non-reduced insulin receptor has a molecular weight in the $400 \mathrm{~K}$ range.

These results also show that the insulin binding sites in membranes from omental and subcutaneous tissue have similar molecular weights. Therefore, as indicated by two different receptor isolation procedures, the changes in insulin binding characteristics cannot be explained by molecular weight differences in the non-reduced receptor species, at least as examined by the cross-linking technique and sodium dodecyl sulphate electrophoresis.

The Percoll method used to isolate plasma membranes for affinity labelling studies has an additional advantage. It is more efficient than the more laborious technique of first isolating the adipocytes, cross-linking radiolabelled insulin to the insulin receptor, and then membrane isolation. This consideration becomes important in the studies of non-obese subjects with limited amounts of available fat. Primarily for this reason, the molecular weight comparisons of non-obese and obese adipocyte receptors were carried out using purified plasma membranes from fat biopsies.

Figure 4 shows the results from two obese and two non-obese subjects. The membranes from both groups have a high molecular weight insulin binding species $(429 \mathrm{~K}-390 \mathrm{~K})$ and small amounts of relatively non-specific labelled material of $121 \mathrm{~K}$ and $63 \mathrm{~K}$. There was no difference in the ${ }^{125} \mathrm{I}$-insulin labelling patterns between obese and non-obese individuals, either in subcutaneous or omental fat. In these studies the amount of plasma membrane used for affinity labelling varied depending on the recovery from the adipose tissue. It is not possible therefore to compare the actual content of the receptors in obese and normal tissue by examining the autoradiograms.

The receptor subunit structure was examined in these subjects by subjecting the labelled receptors to $100 \mathrm{mmol} / 1 \beta$-mercaptoethanol (Fig. 5). A major $125 \mathrm{~K}$ subunit is present in all receptor preparations along with a minor $85 \mathrm{~K}$ component. Again no difference is evident between obese and non-obese or between subcutaneous and omental fat. Studies also were conducted using ${ }^{125}$ I-insulin cross-linked to isolated adipocytes from omental and subcutaneous fat (data not shown). In agreement with the results in Figure 5, the major subunit in both groups of cells had a molecular weight of $125 \mathrm{~K}$.

\section{Discussion}

The basic alteration(s) responsible for the insulin resistance of target cells in obesity is unknown. Current speculation regarding the site of the alteration has focussed on either a change in the insulin receptor content or a change in post-receptor (post-binding) events [2]. 
There is evidence, summarized below, that supports both possibilities.

Several studies have described an overall loss of insulin receptors in adipocytes taken from obese subjects [3-6]. This finding argues for the first possibility, i. e. the presence of a receptor alteration in obesity. Other work, however, has found only a change in the cell surface concentration of the adipocyte receptor without a change in total receptor content [7-9]. The results of the present study support these latter data, which question whether a receptor defect exists in the affected cells.

We investigated both omental adipocytes as well as the usually studied subcutaneous fat cells. For both cell types, the insulin binding characteristics expressed per cell did not differ significantly in adipocytes isolated from the lean control subjects. The only change detected in obesity was a decrease in the number of receptors per unit of cell surface area, $i$. e. a dilution in the concentration of surface receptors in the absence of a change in total receptor content.

Clearly, if the total receptor content of the adipocytes is less than normal, a strong argument can be made for an alteration at the level of the receptor. In contrast, a simple dilution of the insulin receptor over the cell surface is more difficult to evaluate in terms of its role in insulin resistance. The adipocytes enlarge during the development of the obese condition and this factor alone can account for a change in the cell surface concentration of the receptor. Since very little information is available regarding the coupling of the insulin receptor to the cellular effector systems, it is not possible to argue with any confidence that this dilution effect gives rise to defective receptor function.

The insulin-mediated responses of adipocytes from overweight subjects have been measured in attempts at characterizing the changes present in obesity. Alterations in the maximum responses to insulin have been reported for glucose metabolism [9] and glucose transport $[8,25]$. Also a change (e.g. right-ward shift) in the insulin-dose response curve has been described for these processes $[8,25]$. The change in the maximum response is compatible with a post-binding alteration [2]. The right-ward shift in the dose-response curve is more difficult to interpret since it may involve the ill-defined processes that link the receptor to the effector systems. Whether dilution of the receptors over the cell surface contributes to any uncoupling between these structures and the effector systems is impossible to judge at this time.

Although changes in insulin action occurs in glucose metabolism, another system, antilipolysis, retains its normal response to insulin in adipocytes from obese subjects [26]. This finding, plus the other evidence for post-receptor alterations in glucose metabolism and transport outlined above, suggest that the major change(s) in affected cells occur, at selected sites beyond the receptor.

Since insulin binding studies examine only one aspect of the insulin receptor, we also undertook an investigation of the molecular weight of the receptor, us- ing an affinity labelling procedure [19]. Although this method has a labelling efficiency of only $20 \%$ for the non-reduced receptor [23], it is the most efficient method available to examine the molecular weights of the non-reduced receptor and its insulin binding subunit. Again, in agreement with the similarities in their respective insulin binding properties and with the concept of a post-binding alteration, no change in the molecular weight of the receptor was detected in obesity. Thus, dilution of cell surface receptors remains the only change detected in omental and subcutaneous adipocytes from obese subjects. However, it cannot be excluded that a subpopulation of receptors exists which is not affinity labelled and which may differ in obesity.

The present study also provided the opportunity to examine the interesting difference noted previously between the receptor affinities of omental and subcutaneous adipocytes from lean individuals [11]. The molecular weight studies showed that membranes from both tissues contained one major non-reduced insulin binding species of $390-425 \mathrm{~K} \mathrm{M}_{\mathrm{r}}$ Sulphydryl reduction generated a major insulin binding subunit of $125 \mathrm{~K}$ and a minor $85 \mathrm{~K}$ component from both types of tissues.

It was interesting that affinity labelling the isolated fat cells rather than the purified plasma membrane fraction from fat pieces produced different non-reduced receptor species. With isolated cells, a major species of $M_{r}$ $285 \mathrm{~K}$ was evident with a prominent amount of a $355 \mathrm{~K}$ component and small amounts of $427 \mathrm{~K}$ and $182 \mathrm{~K}$ species. Although this difference between isolated fat cells and plasma membranes is striking, the results with the cells are quite similar to those reported for isolated rat adipocytes [27] and to the recent findings of Berhanu et al. [28], who examined the receptors of isolated human adipocytes.

It is possible that the difference observed between the fat cell membranes and isolated adipocytes is caused by the collagenase treatment used in the cell isolation procedure. The collagenase preparation contains several different proteases, any one of which could act on the insulin receptor since it is highly sensitive to protease activity [24]. A second possibility is that the membrane preparation contains a large number of insulin receptors of $400 \mathrm{~K} \mathrm{M}_{\mathrm{r}}$ derived from other cell types, i.e. from cells other than adipocytes. The various proportions between other cells and adipocytes in human fat biopsies are not known, but in rat fat the adipocytes represent $35 \%$ of the total cell number [29]. However, because of the much greater size of the adipocytes, the amount of fat cell plasma membrane probably accounts for the majority of the plasma membrane content of adipose tissue. Since we chose a method specifically designed to isolate adipocyte plasma membranes from fat pieces as well as from isolated adipocytes [16], the plasma membrane fraction used in the present studies is probably more representative of the adipocyte than of the stromal cells. Moreover, stromal cells, such as fibroblasts [30], have fewer insulin receptors than adipocytes. Based on these considerations, it seems unlikely that the $400 \mathrm{~K}$ species is derived from a stromal cell type. 
A third and more intriguing possibility to explain the difference found between affinity labelled membranes and isolated adipocytes is that the binding of insulin to the surface of the intact cells causes the generation of some of these species. In support of this possibility Berhanu et al. [28] found a time-dependent production of different molecular weight species after photoaffinity labelling of the adipocyte cell surface receptor. Thus, covalent attachment of insulin to the receptor may cause the adipocyte to "process" this complex and alter its molecular weight.

Regardless of the causes of the different molecular weight species, omental and subcutaneous adipocytes isolated by collagenase treatment have the same species in the same relative proportions. Therefore, the cause of the difference in binding affinity between these two cell types probably arises from another reason, like differences in membrane lipid composition [31] or in membrane modulators of affinity [32].

In summary, obesity does not change the molecular weight of the adipocyte insulin receptor, its insulin binding properties, or its content in the enlarged adipocyte. These findings suggest that the major alteration responsible for the insulin resistance of adipocytes from obese subjects involves post-receptor sites.

\begin{abstract}
Acknowledgements. The authors thank Dr. J. Amatruda for helpful review of the manuscript and Dr. P. Berhanu for making available unpublished data. The present study was supported by National Institutes of Health Grant AM 25116, and The Swedish Medical Association, The Karolinska Institute, the Swedish Diabetes Association and the Foundations of Folksam, Osterman and Nordic Insulin. J.N.L. is a recipient of the National Institutes of Health Research Career Development Award AM 00470.
\end{abstract}

\section{References}

1. Kreisberg R, Boshell B, DiPlacido J, Roddman R (1967) Insulin secretion in obesity. N Engl J Med 276:314-319

2. Olefsky $J(1981)$ Insulin resistance and insulin action. Diabetes 30: 148-162

3. Olefsky $J(1976)$ Decreased insulin binding to adipocytes and circulating monocytes in obesity. J Clin Invest 57:1165-1172

4. Kolterman O, Reaven G, Olefsky J (1979) Relationship between in vivo insulin resistance and decreased insulin receptors in obese man. J Clin Endocrinol Metab 48: 487-494

5. Harrison L, Martin F, Melick R (1976) Correlation between insulin receptor binding in isolated fat cells and insulin sensitivity in obese human subjects. J Clin Invest 58: 1435-1441

6. Kolterman O, Insel J, Saekow M, and Olefsky J (1980) Mechanisms of insulin resistance in human obesity. $J$ Clin Invest 65 : 1272-1284

7. Amatruda M, Livingston J, Lockwood D (1975) Insulin receptor: role in the resistance of human obesity to insulin. Science 188: 264-266

8. Pedersen O, Hijollunk E, Schwartz N (1982) Insulin receptor binding and insulin action in human fat cells: effects of obesity and fasting. Metabolism 31: 884-895

9. Lönnroth P, DiGirolamo M, Krotkiewski M, Smith U (1983) Insulin binding and responsiveness in fat cells from patients with reduced glucose tolerance and type II diabetes. Diabetes 32 : $748-754$

10. Borkan G, Cerzof S, Robbins A, Hults D, Silbert C, Silbert J (1982) Assessment of abdominal fat content by computed tomography. Am J Clin Nutr 36: 172-177

11. Bolinder J, Kager L, Östman J, Arner P (1983) Differences at the receptor and postreceptor levels between human omental and subcutaneous adipose tissue in the action of insulin on lipolysis. Diabetes 32: 117-123

12. Sjöstrom L, Björntorp P, Vrana J (1971) Microscopic fat cells: size measurements on frozen adipose tissue in comparison with automatic determinations of osimum-fixed fat cells. J Lipid Res 12: $521-530$

13. Hirsch J, Gallian E (1968) Method for the determinations of adipose cell size and cell number in man and animals. J Lipid Res 9 : $110-119$

14. Zinder Z, Shapiro B (1971) Effect of cell size on epinephrine- and $\mathrm{ACTH}$-induced fatty acid release from isolated fat cells. $J$ Lipid Res 12: 91-95

15. Rodbell M (1964) Metabolism of isolated fat cells. I. Effects of hormone on glucose metabolism and lipolysis. J Biol Chem 239: $375-380$

16. Belsham G, Denton R, Tanner M (1980) Use of novel rapid preparation of fat-cell plasma membranes employing Percoll to investigate the effects of insulin and adrenaline on membrane protein phosphorylation within intact fat-cells. Biochem J 192:457-467

17. Gliemann J, Sonne $O$ (1978) Binding and receptor-mediated degradation of insulin in adipocytes. J Biol Chem 253: 7857-7863

18. Scatchard $G$ (1949) The attraction of protein for small molecules and ions. Ann NY Acad Sci 51: 660-672

19. Pilch P, Czech M (1979) Interaction of cross-linking agents with the insulin effector system of isolated fat cells. J Biol Chem 254: 3375-3381

20. Weber K, Pringle J, Osborn M (1972) Measurement of molecular weights by electrophoresis on SDS-acrylamide gel. Methods Enzymol 26:3-27

21. Laemmli $U$ (1970) Cleavage of structural proteins during the assembly of the head of bacteriophage $T_{4}$. Nature 227:680-685

22. Livingston J, Purvis B (1980) Effects of wheat germ agglutinin on insulin binding and insulin sensitivity of fat cells. Am J Physiol 238: E267-E275

23. Lerea K, Livingston J (1983) The different receptor species of liver have similar complex insulin binding properties. Biochem Biophys Res Commun 114: 1042-1047

24. Massague J, Pilch P, Czech M (1980) Electrophoretic resolution of three major insulin-receptor structures with unique subunit stoichiometries. Proc Natl Acad Sci (USA) 77: 7137-7141

25. Ciaraldi T, Kolterman O, Olefsky J (1981) Mechanism of the postreceptor defect in insulin action in human obesity. $J$ Clin Invest $68: 875-880$

26. Arner P, Bolinder J, Engfeldt P, Ostman J (1981) The antilipolytic effect of insulin in human adipose tissue in obesity, diabetes mellitus, hyperinsulinemia, and starvation. Metabolism 30: 753-760

27. Massague J, Pilch P, Czech M (1981) A unique proteolytic cleavage site on the $\beta$ subunit of the insulin receptor. J Biol Chem 256 : 3182-3190

28. Berhanu P, Kolterman O, Baron A, Tsai P, Olefsky J, Brandenburg $D$ (1983) Insulin receptors in isolated human adipocytes, Characterization by photoaffinity labeling and eviclence for internalization and cellular processing. J Clin Invest 72: 1958-1970

29. Rodbell, M (1964) Localization of lipoprotein lipase in fat cells of rat adipose tissue. J Biol Chem 239: 753-755

30. Mott D, Howard B, Bennett P (1979) Stoichiometric binding and regulation of insulin receptors on human diploid fibroblasts using physiologic insulin levels. J Biol Chem 254:8762-8767

31. Gould R, Ginsberg B, Spector A (1982) Lipid effects on the binding properties of a reconstituted insulin receptor. J Biol Chem 257 : $477-484$

32. Maturo J, Hollenberg M (1978) Insulin receptor: interaction with non-receptor glycoprotein from liver cell membranes. Proc Natl Acad Sci (USA) 75: 3070-3074

Received: 19 January 1984

and in final form: 17 July 1984

Dr. P.Arner

Department of Medicine

Huddinge Hospital

S-141 86 Huddinge

Sweden 